\title{
Responses of $p s b A$, hli and ptox genes to changes in irradiance in marine Synechococcus and Prochlorococcus
}

\author{
Gry Mine Berg ${ }^{1, *}$, Jeff Shrager ${ }^{2}$, Gert van Dijken ${ }^{1}$, Matthew M. Mills ${ }^{1}$, \\ Kevin R. Arrigo ${ }^{1}$, Arthur R. Grossman ${ }^{2}$ \\ ${ }^{1}$ Department of Environmental Earth System Science, Stanford University, Stanford, California 94305, USA \\ ${ }^{2}$ Department of Plant Biology, The Carnegie Institution for Science, 260 Panama Street, Stanford, California 94305, USA
}

\begin{abstract}
Expression of 3 gene families involved with photoacclimation - psbA (encoding the photosystem II reaction center protein D1), hli (encoding the high-light inducible proteins), and ptox (encoding the plastid terminal oxidase) - was compared in the marine cyanobacteria Synechococcus WH8102 and Prochlorococcus MED4 acclimated to either low or high light. These 2 strains, adapted for growth in oligotrophic marine environments, have distinct light-harvesting systems and respond differently to changes in irradiance. In response to growth at higher irradiance, Synechococcus WH8102 increased expression of the $p s b A$ multigene family (psbA1-4) 5-fold. Within this gene family, the expression of psbA2 increased 60-fold. Expression of 4 hli genes increased 2- to 5 -fold, whereas expression of the ptox gene decreased 3-fold. In comparison, expression of the psbA gene increased 2-fold in Prochlorococcus MED4 cultures grown at higher irradiances. Expression of the Prochlorococcus MED4 hli6-9 and hli16-19 operons increased 11- to 14-fold, while ptox expression increased 3-fold. Using $p s b A$ induction as a standard for acclimation to changes in irradiance, we observed that the induction ratio of ptox:psbA1 and hli:psbA1 was 144 and 70 times greater, respectively, in Prochlorococcus MED4 compared with Synechococcus WH8102. These observations suggest that induction of ptox and hli may play a key role in the phototolerance of Prochlorococcus MED4. Conversely, the induction of $p s b A$, and the synthesis of the PSII reaction center protein D1, may be critical for the acclimation of Synechococcus WH8102 to high irradiances.
\end{abstract}

KEY WORDS: Synechococcus WH8102 - Prochlorococcus MED4 · Photoacclimation · Photoinhibition · Gene expression $\cdot p s b A \cdot h l i \cdot p t o x \cdot$ Fluorescence characterization $\cdot$ Carbon fixation

\section{INTRODUCTION}

Marine cyanobacteria dominate the brightly lit surface waters of ocean gyres where nutrient availability is highly restricted (Bouman et al. 2006, Fuller et al. 2006). Two clades that are adapted to growth under these conditions, and that overlap in their distributions, are represented by the strains Synechococcus WH8102 (Palenik et al. 2003) and Prochlorococcus marinus MED4 (Rocap et al. 2003, Scanlan et al. 2009). Despite their coexistence under similar environmental conditions (Zwirglmaier et al. 2007, 2008), the organisms in these genera are defined by distinctly different light- harvesting systems and nutrient requirements (Ting et al. 2002). Synechococcus WH8102 harvests light energy mostly through absorption by phycobilisomes (PBS) - macromolecular protein complexes that are peripheral to the thylakoid membrane and are associated mainly with photosystem II (PSII) (Grossman et al. $1993,2001)$. PBS are composed of a central core of the pigmented biliprotein allophycocyanin (AP, encoded by the apc genes), from which rods of the pigmented biliproteins phycocyanin ( $\mathrm{PC}$, encoded by the rpc genes) and phycoerythrin ( $\mathrm{PE}$, encoded by the cpe genes) radiate outwards (Fig. 1). AP binds the chromophore phycocyanobilin (PCB), PC binds the chro- 
mophores PCB and phycoerythrobilin (PEB), and PE binds the chromophores PEB and phycourobilin (PUB) to harvest light. In contrast, Prochlorococcus relies on integral thylakoid membrane proteins (Pcbs) that bind divinyl chlorophyll $a$ and $b$ to harvest light energy. The Pcbs of Prochlorococcus MED4 form a ring around PSII (Bibby et al. 2003), their Fig. 1.

High irradiance in the uppermost layer of the ocean can lead to photoinhibition and loss of function of the photosynthetic apparatus. During photosynthesis, an electron from an excited chlorophyll molecule is trans- ferred to the primary electron acceptor pheophytin and then on to the quinone molecules $\left(Q_{A}\right.$ and $\left.Q_{B}\right)$ of the plastoquinone (PQ) pool. From the PQ pool, electrons are transferred to cytochrome $b_{6 f}$, plastocyanin, and finally, through photosystem I (PSI), to reduce NADP ${ }^{+}$ in the classical $\mathrm{z}$ scheme (Fig. 1). Photoinhibition results when the PQ pool becomes over-reduced (Vass et al. 1992) or during charge recombination between PSII acceptor and donor sides (Keren et al. 1997). Overreduction of the PQ pool can generate singlet oxygen species that ultimately cleave and damage the PSII

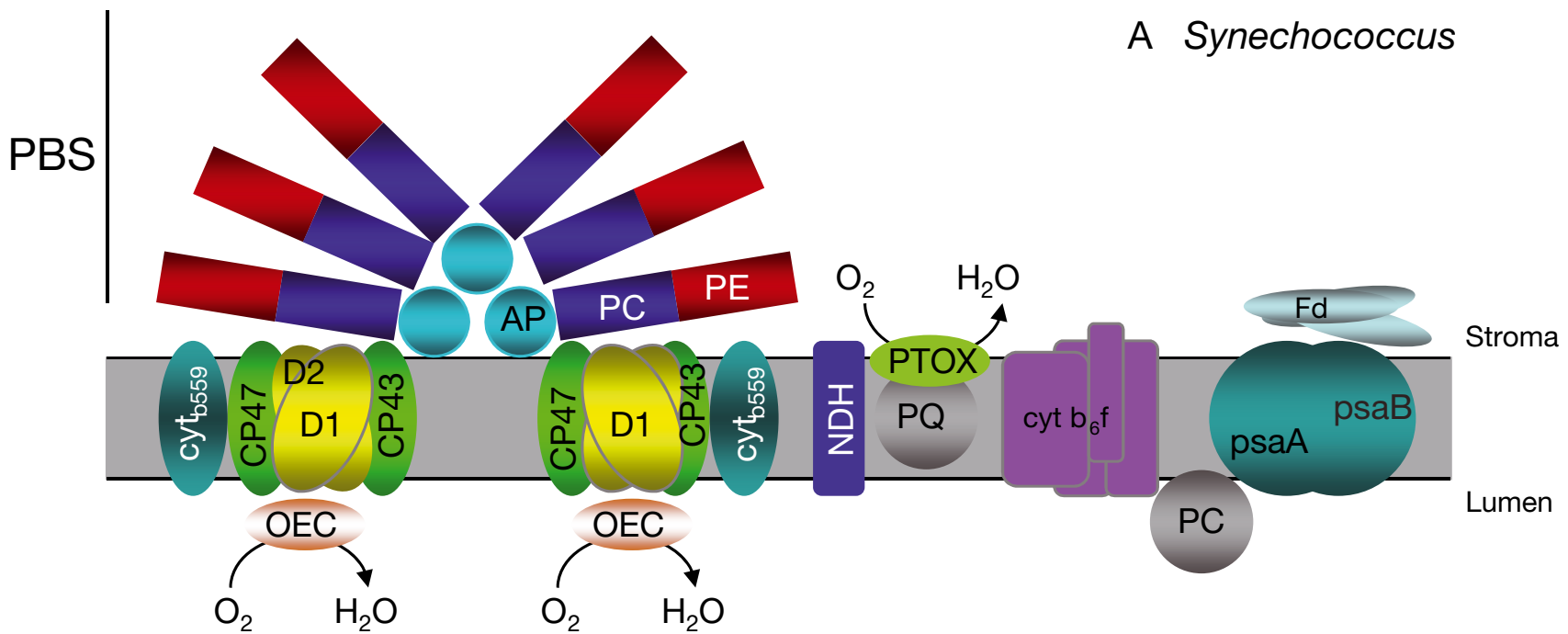

B Prochlorococcus

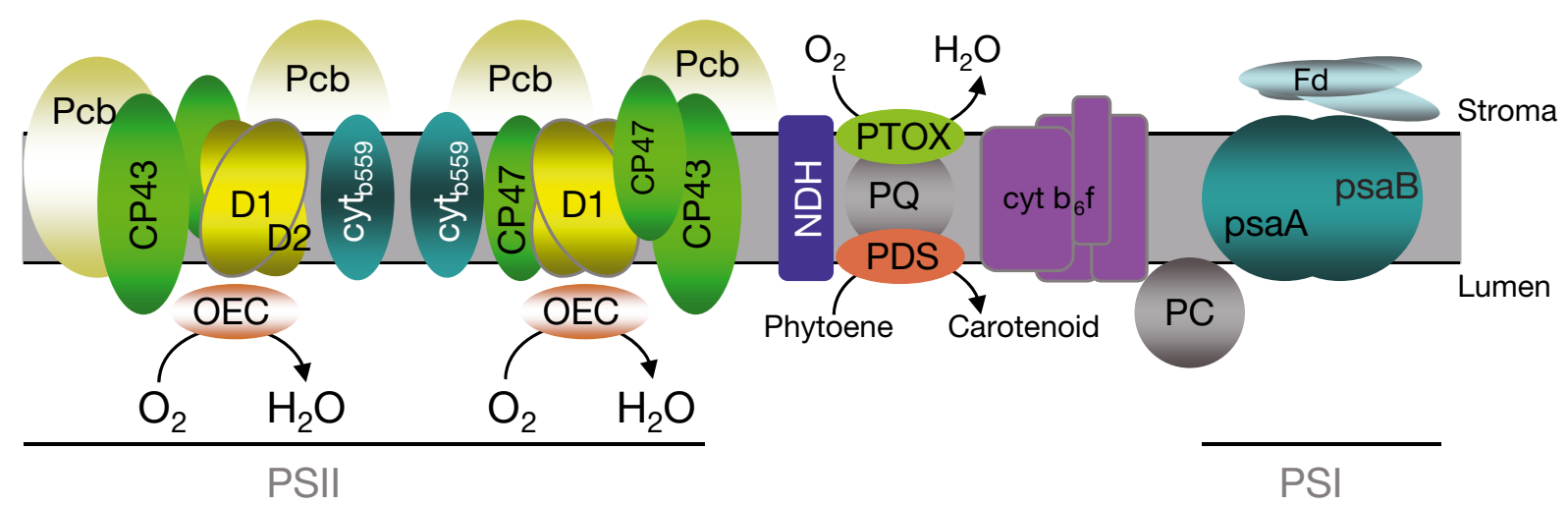

Fig. 1. Schematic illustration of light-harvesting and electron-transport proteins in Synechococcus and Prochlorococcus (adapted from Ting et al. 2002). (A) Synechococcus. The phycobilisome (PBS) light-harvesting system is composed of a core protein, allophycocyanin (AP, shown in turquoise), an inner rod protein, phycocyanin (PC, shown in blue), and the outer rod (shown in red) composed of either 1 or 2 structurally distinct forms of phycoerythrin (PE). (B) Prochlorococcus. The prochlorophyte chlorophyllbinding proteins form a ring around PSII. The NDH (in blue) complex represents a number of possible reductases that reduce the plastoquinone $(\mathrm{PQ})$ pool using stromal reductant (i.e. derived from glycolyis), including a putative NAD(P)H-plastoquinone oxidoreductase which occurs adjacent to plastid terminal oxidase (PTOX) in the Prochlorococcus MED4 genome (McDonald \& Vanlerberghe 2005), NAD(P)H dehydrogenase, ferredoxin-quinone oxidoreductase and glycolate-quinone oxidoreductase, as described in Carol \& Kuntz (2001). D1 and D2 = core proteins of the PSII reaction center; CP43 and CP47 = chl a-binding core

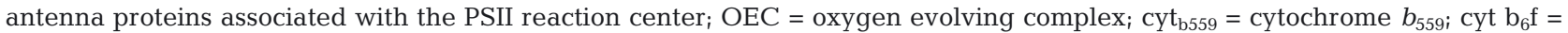
cytochrome $b_{6 \mathrm{f}}$ complex; $\mathrm{Pcb}=$ prochlorophyte chlorophyll-binding protein; $\mathrm{PC}$ (blue) = phycocyanin; PC (grey) = plastocyanin; $\mathrm{PE}=$ phycoerythrin $; \mathrm{PQ}=$ plastoquinone pool $; \mathrm{NDH}=\mathrm{NAD}(\mathrm{P}) \mathrm{H}$ plastoquinone oxidoreductase $; \mathrm{PTOX}=$ plastid terminal oxidase; $\mathrm{PDS}=$ phytoene desaturase $;$ psaA = PSI reaction center apoprotein; Fd = ferredoxin 
core protein D1 (Vass et al. 1992, Clarke et al. 1993, Nishiyama et al. 2006). Damage to D1 results in photoinhibition, which is manifested as a decrease in PSII photochemical efficiency (evidenced by a decrease in the PSII fluorescence yield $\left.\left(F_{\mathrm{v}} / F_{\mathrm{m}}\right)\right)$ and in the rate of photosynthetic carbon fixation (Clarke et al. 1995, Behrenfeld et al. 1998, Six et al. 2007a, Garczarek et al. 2008).

The redox state of the PQ pool plays a key role in the regulation of photosynthetic electron transport and in the susceptibility of the photosynthetic apparatus to photoinhibition. Therefore, photosynthetic organisms have developed a variety of strategies to prevent the PQ pool from becoming over-reduced. One strategy is to dissipate excess absorbed light energy as heat, possibly involving the high-light inducible proteins (He et al. 2001, Havaux et al. 2003). A second strategy involves transferring electrons from the PQ pool to molecular oxygen via the action of terminal oxidases (Bennoun 1982, 2002, Berry et al. 2002, Hart et al. 2005, Bailey et al. 2008). When these strategies are not sufficient to prevent photoinhibition, D1 protein synthesis is upregulated to replace damaged D1 proteins and restore function to the PSII reaction center (Schaefer \& Golden 1989a,b, Clarke et al. 1993,1995, Long et al. 1994, Campbell et al. 1998a). With respect to cyanobacteria, genes encoding 3 families of proteins have been shown to be important for the management of absorbed excitation energy: (1) the hli genes that encode the high-light inducible proteins (HLIPs); (2) the ptox gene that encodes the plastid terminal oxidase (PTOX); and (3) the psbA genes that encode the PSII reaction center core protein D1.

Investigations into the function of HLIPs in freshwater cyanobacteria suggest that these proteins absorb and dissipate excess energy (He et al. 2001, Havaux et al. 2003). It has also been suggested that they transiently bind chlorophyll (Funk \& Vermaas 1999) and play a role in the regulation of tetrapyrrole biosynthesis (Xu et al. 2002). Although most probably integral to the thylakoid membranes, it is not clear with which photosystem these proteins associate. While earlier investigations linked them with PSII (Promnares et al. 2006, Yao et al. 2007), a more recent investigation has shown that 3 of the 4 extant HLIPs of Synechocystis PCC 6803 are associated with PSI (Wang et al. 2008). Marine cyanobacteria have a greater number of HLIPs compared with their freshwater counterparts, and some of these may respond to stressors other than light, including viral infection (Lindell et al. 2007) and nitrogen limitation ( $\mathrm{Su}$ et al. 2006, Tolonen et al. 2006). While Synechococcus WH8102 has 8 hli genes, Prochlorococcus MED4 has 22, the greatest number of hli genes observed in any of the cyanobacteria sequenced thus far (Bhaya et al. 2002).
In addition to the HLIPs, there are a number of oxidases that serve as electron valves, extracting electrons between PSII and PSI. These enzymes include PTOX (McDonald et al. 2003), cytochrome $c$ oxidase (Berry et al. 2002), and the alternative quinol oxidases (Hart et al. 2005). Cytochrome $c$ oxidase is essential for respiration and provides energy needed for maintenance of cellular functions in the dark. The alternative quinol oxidase is hypothesized to have a similar function to cytochrome $c$ oxidase but is much less well characterized and is absent in marine Prochlorococcus (Hart et al. 2005). In contrast, PTOX plays potentially important roles in photosynthetic electron transport, as well as in respiratory electron transport, and also in reactions critical for the synthesis of carotenoids. In the light, PTOX may mediate the re-oxidation of the PQ pool reduced by PSII (Cournac et al. 2000, Bailey et al. 2008). In the dark, PTOX may oxidize the PQ pool reduced internally via $\mathrm{NADP}(\mathrm{H})$ dehydrogenase $(\mathrm{NDH}), \mathrm{PQ}$ oxidoreductase (Bennoun 1982, 2002, Rumeau et al. 2007), or phytoene desaturase (Carol \& Kuntz 2001) (Fig. 1). Putative ptox genes encoded by both Synechococcus WH8102 and Prochlorococcus MED4 have been characterized in natural cyanobacterial assemblages in ocean gyres (McDonald \& Vanlerberghe 2005), and recent investigations in Prochlorococcus sp. have demonstrated that the ptox gene is regulated by high-light exposure (Steglich et al. 2006).

Active repair of the PSII reaction center protein D1, involving rapid changes in $p s b A$ gene expression and D1 protein synthesis, is an effective short-term strategy to cope with rapidly changing light intensities (Six et al. 2007b). While Prochlorococcus MED4 has a single D1 isoform (D1:1) encoded by 1 psbA gene, Synechococcus WH8102 has 2 D1 isoforms (D1:1 and D1:2) encoded by 4 psbA genes (Palenik et al. 2003). In the latter clade, the ratio of D1:1 to D1:2 isoforms may change with light intensity and with increased photodamage (Garczarek et al. 2008). Despite the difference in $p s b A$ gene copy number, increases in total $p s b A$ transcript accumulation are observed in both marine Prochlorococcus and Synechococcus upon exposure to higher irradiance (Steglich et al. 2006, Six et al. 2007a, Garczarek et al. 2008), and the level of the Prochlorococcus MED4 psbA transcript is directly correlated with light intensity over the diel cycle (Zinser et al. 2009).

To gain insight into whether Prochlorococcus MED4 and Synechococcus WH8102 acclimate to changes in irradiance in a similar manner given their very different light harvesting systems, we shifted cultures from very low light to a higher irradiance. We also hoped to establish whether or not changes in cell physiology such as carbon fixation and the efficiency of excitation energy capture by closed PSII $\left(F_{\mathrm{v}} / F_{\mathrm{m}}\right)$-correlated 
with changes in gene expression. To this end, we monitored changes in the levels of transcripts of genes unique to each species, including genes encoding components of their respective light-harvesting systems, as well as genes common to both species, including psbA, hli and ptox. We specifically tested the hypothesis that homologous genes, i.e. genes with a certain sequence similarity, encoding proteins of similar function, would have similar patterns of expression in both species.

\section{MATERIALS AND METHODS}

Culture growth conditions. Axenic, semi-continuous cultures of Synechococcus WH8102 (CCMP2370) were grown at $22^{\circ} \mathrm{C}$ in $0.2 \mu \mathrm{m}$ filtered and autoclaved SN medium (Waterbury et al. 1986) under continuous white light at intensities of 15 and $50 \mu \mathrm{mol}$ quanta $\mathrm{m}^{-2} \mathrm{~s}^{-1}$. Axenic, semi-continuous cultures of Prochlorococcus MED4 (CCMP2389) were grown in Pro99 medium at $19^{\circ} \mathrm{C}$ exposed to continuous irradiance of either 20 or $160 \mu \mathrm{mol}$ quanta $\mathrm{m}^{-2} \mathrm{~s}^{-1}$. Both species were grown in triplicate, aerated, glass flasks (volume: 2 l) and were acclimated to the lower or higher growth irradiance for $3 \mathrm{wk}$ before samples were collected and analyzed. The higher light intensities represented the maximum intensities that the cells could tolerate when shifted in 1 step from the lower growth irradiances. Synechococcus WH8102 has been successfully grown in up to $650 \mu \mathrm{mol}$ quanta $\mathrm{m}^{-2} \mathrm{~s}^{-1}$ of continuous white light when progressively acclimated by no more than 2 -fold increases in irradiation (Six et al. 2004). Increases in irradiance of 5-fold or more in 1 step will typically lead to photoinhibition of cell growth and death (Six et al. 2004). This has also been observed for Synechococcus WH7803, which can be shifted by only 2- or 3-fold in irradiance at a time (Kana \& Glibert 1987). Once the cultures were acclimated they were sampled for carbon fixation, fluorescence yield, and the levels of specific transcripts using quantitative polymerase chain reaction (qPCR) analyses.

Fluorescence yield. The PSII fluorescence yield $\left(F_{\mathrm{v}} / F_{\mathrm{m}}\right)$ was measured using a pulse-amplitude-modulated (PAM) fluorometer (Water-PAM, Walz). Prior to measurement, the PAM was zeroed with $4 \mathrm{ml}$ sterilefiltered (pore size $0.2 \mu \mathrm{m}$ ) culture medium. Approximately $4 \mathrm{ml}$ culture was collected and dark-adapted for 15 min before the modulated (non-actinic) measuring light (peaking at $460 \mathrm{~nm}$ ) was switched on to determine the minimum fluorescence $\left(F_{0}\right)$ of the darkadapted sample. Subsequently, the maximum fluorescence $\left(F_{\mathrm{m}}\right)$ of that sample was determined following a saturating light pulse of $4000 \mu \mathrm{mol}$ quanta $\mathrm{m}^{-2} \mathrm{~s}^{-1}$, peaking at $660 \mathrm{~nm}$, for $0.8 \mathrm{~ms} . F_{\mathrm{v}} / F_{\mathrm{m}}$ was calculated as $\left(F_{\mathrm{m}}-F_{0}\right) / F_{\mathrm{m}}$. Because the light source used to determine $F_{\mathrm{m}}$ was saturating, closing all the reaction centers, the spectral quality of this light source should have a minimal effect on this measurement. PBS-containing cyanobacteria have lower fluorescence yields than do vascular plants, prochlorophytes or eukaryotic phytoplankton because $F_{0}$ includes emissions from phycobiliproteins in addition to PSII (Campbell et al. 1996, 1998b). As such, we cannot directly compare the $F_{\mathrm{v}} / F_{\mathrm{m}}$ values between PBS- and non-PBS-containing cyanobacteria. Nevertheless, we can compare relative changes within each taxon as an indicator of PSII function.

Photosynthesis-irradiance $(\boldsymbol{P}-\boldsymbol{E}) . P-E$ relationships were determined from ${ }^{14} \mathrm{C}$-bicarbonate incorporation as described in Arrigo et al. (2010) with the exception that the samples were incubated for $1 \mathrm{~h}$ at the culture growth temperature $\left(23\right.$ or $\left.19^{\circ} \mathrm{C}\right)$. Chlorophyll a $(\mathrm{chl}$ a)normalized carbon uptake was calculated from radioisotope incorporation and the concentration of $\mathrm{chl}$ a (Arrigo et al. 2010). Data were fitted by leastsquares non-linear regression to the $P-E$ equation of Platt et al. (1980) to derive photosynthetic parameters. The photosynthetic parameters discussed here include $P_{\max }^{*}\left(\mu \mathrm{g} \mathrm{C} \mu \mathrm{g}^{-1} \mathrm{chl} a \mathrm{~h}^{-1}\right)$, the maximum chl a-normal-

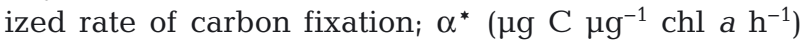
( $\mu \mathrm{mol}$ photons $\left.\mathrm{m}^{-2} \mathrm{~s}^{-1}\right)^{-1}$, the chl a-normalized initial slope of the $P-E$ curve, an index of photosynthetic efficiency; and $E_{\mathrm{k}}\left(E_{\mathrm{k}}=P_{\max }^{*} / \alpha^{*}, \mu \mathrm{mol}\right.$ photons $\left.\mathrm{m}^{-2} \mathrm{~s}^{-1}\right)$, the irradiance at which photosynthesis approaches saturation, an index of photoacclimation.

Chl a concentration. The concentration of chl a in the Prochlorococcus MED4 cultures was determined by filtering triplicate $5 \mathrm{ml}$ culture aliquots onto $25 \mathrm{~mm}$ Whatman GF/F filters and extracting the filters in the dark at $4^{\circ} \mathrm{C}$ for $24 \mathrm{~h} \mathrm{in} 5 \mathrm{ml}$ of $90 \%$ acetone. Chl a was measured fluorometrically using a Turner Fluorometer 10-AU (Turner Designs) according to Holm-Hansen et al. (1965). The concentration of chl a in the Synechococcus WH8102 cultures was determined by filtering triplicate $5 \mathrm{ml}$ culture aliquots onto $25 \mathrm{~mm}$ Whatman GF/F filters that were placed into bead-beater tubes. After addition of $1 \mathrm{ml} 90 \%$ acetone, the filters were extracted overnight. The following day, a volume corresponding to $50 \mu \mathrm{l}$ glass beads was added to the tubes and the samples were processed at maximum speed for $30 \mathrm{~s}$ in a Mini Beadbeater (Biospec Products) followed by centrifugation at $13400 \mathrm{rpm}$ $(12100 \times g)$ in a microfuge for $1 \mathrm{~min}$ at $4^{\circ} \mathrm{C}$. The supernatant was diluted 1:5 in $90 \%$ acetone and measured fluorometrically.

RNA isolation. Total RNA from cultures acclimated under low light (LL) and high light (HL) was extracted using phenol-chloroform (Sambrook et al. 1989). 
Briefly, pelleted cells were lysed in $500 \mu \mathrm{l}$ SDS-EB buffer (2\% SDS, $400 \mathrm{mM} \mathrm{NaCl}, 40 \mathrm{mM}$ EDTA, $100 \mathrm{mM}$ Tris $\mathrm{HCl}, \mathrm{pH} 8.0), 50 \mu \mathrm{l}$ M sodium acetate (pH 5.0), and $600 \mu \mathrm{l}$ phenol-chloroform-isoamyl alcohol (25:24:1, v/v) by pipetting the cell suspension up and down. Following centrifugation (13400 rpm $\left.[12100 \times g], 4^{\circ} \mathrm{C}, 5 \mathrm{~min}\right)$, the aqueous supernatant $(\sim 600 \mu \mathrm{l})$ was transferred to a new tube and extracted a second time with 1 vol $(600 \mu \mathrm{l})$ of phenol-chloroform-isoamyl alcohol. After a second centrifugation (13 $\left.400 \mathrm{rpm}[12100 \times \mathrm{g}], 4^{\circ} \mathrm{C}, 5 \mathrm{~min}\right), 1 \mathrm{vol}$ chloroform was added to the supernatant and the sample was centrifuged once more. Following transfer of the aqueous supernatant, 2 vols of $100 \%$ ice-cold ethanol and $50 \mu \mathrm{l} 10 \mathrm{M} \mathrm{LiCl}_{2}$ were added to the sample which was incubated at $-20^{\circ} \mathrm{C}$ for $1 \mathrm{~h}$ to precipitate the RNA. Nucleic acids were pelleted by centrifugation (12 $\left.000 \mathrm{rpm}[9700 \times \mathrm{g}], 4^{\circ} \mathrm{C}, 25 \mathrm{~min}\right)$. The supernatant was discarded and the pellet was rinsed with $80 \%$ ethanol, air-dried, and resuspended in sterile distilled water. The total RNA concentration was determined by absorption at $260 \mathrm{~nm}$, and $20 \mu \mathrm{g}$ aliquots were treated twice with $5 \mathrm{U}$ of RNase-free DNase I (Qiagen) in a total volume of $50 \mu \mathrm{l}$ according to the manufacturer's instructions. RNA quality was assessed from the $A_{260} / A_{280} \mathrm{~nm}$ ratio and from denaturing agarose gel electrophoresis.

qPCR. Three $\mu \mathrm{g}$ of total RNA and 200 U of Superscript III reverse transcriptase (Invitrogen) were used in reverse transcription reactions to generate cDNA. With each reaction, we performed a negative control in which Superscript III was omitted from the reaction. The products of the reactions, with and without Superscript III, were diluted 50-fold and used as templates for qPCR amplifications using the DyNAmo HS SYBR green kit (Finnzymes) and specific primer pairs designed to amplify $200 \mathrm{bp}$ regions of selected genes (Table 1). Each qPCR reaction contained $10 \mu \mathrm{l}$ of DyNAmo HS SYBR green mixture, $1.5 \mu \mathrm{M}$ each of the forward and reverse primers, $4 \mu \mathrm{l}$ of water and $2 \mu \mathrm{l}$ of 1:50 diluted reverse transcription product in a total volume of $20 \mu \mathrm{l}$.

The levels of specific transcripts were quantified using an MJ Research DNA engine with a Chromo-4 continuous fluorescence detector (Bio-Rad) using the following amplification protocol: 1 cycle at $95^{\circ} \mathrm{C}$ for $10 \mathrm{~min}, 40$ cycles at $94^{\circ} \mathrm{C}$ for $10 \mathrm{~s}, 55^{\circ} \mathrm{C}$ for $15 \mathrm{~s}, 72^{\circ} \mathrm{C}$ for $15 \mathrm{~s}$, and a final incubation at $72^{\circ} \mathrm{C}$ for $10 \mathrm{~min}$. The melting curve thermal profile, from 65 to $95^{\circ} \mathrm{C}$, was used to distinguish specific from non-specific amplification (Ririe et al. 1997). The PCR threshold cycle $\left(C_{t}\right.$ value) was determined following baseline subtraction at a constant fluorescence level. Duplicate qPCRs were performed for each sample, and all reactions were repeated independently to evaluate the repro- ducibility of the results. Data were normalized to the expression of the housekeeping gene $r n p B$, encoding RNaseP. The relative difference between the target gene and the housekeeping gene (control) was calculated using the $\Delta C_{t}$ method according to $\Delta C_{t}=$ $2^{-\left[C_{t} \text { (target) }-C_{t} \text { (control) }\right]}$ and the relative fold change between the HL and LL condition (HL/LL) was calculated using the $\Delta \Delta C_{t}$ method, where $\Delta \Delta C_{t}=$ $2^{-\left\{\left[C_{t}(\mathrm{HL})-C_{t}(\text { control })\right]-\left[C_{t}(\mathrm{LL})-C_{t}(\text { control })\right]\right\}}$.

Gene-specific primers (Table 1) were designed using the Primer3 program (Rozen \& Skaletsky 2000) with default parameters (http://frodo.wi.mit.edu/primer3/). We designed gene-specific primers for 3 of the 4 Synechococcus WH8102 psbA gene sequences ( $p s b A 3$ and psbA4 were indistinguishable at the nucleotide level and were treated as a single gene) by creating 50 primer pairs for each of the SYN0983 (psbA1), SYN1470 (psbA2) and SYN2151/SYN 1919 (psbA3/ psbA4) sequences using Primer3. The resulting table of 50 primer pairs per gene, along with the sequence for each gene, was uploaded into the BioBike biocomputing platform (www.biobike.org), and special purpose Lisp code was used to pull all the sub-sequences that would be extracted by these primers from the genes. These sub-sequences (virtual PCR products) were cross-blasted with one another, and a set of primers was chosen that created a set of resulting sequences with the least combined overlap. To ensure similar amplification efficiencies (difference $<8 \%$ ) for target and housekeeping genes, standard curves were generated for each set of primers according to Berg et al. (2008).

\section{RESULTS}

\section{PSII photochemical efficiency}

Maximal $F_{\mathrm{v}} / F_{\mathrm{m}}$ was lower in both taxa in the HL compared with the LL treatment (Fig. 2A). Whereas the decrease in $F_{\mathrm{v}} / F_{\mathrm{m}}$ under HL was a modest $23 \%$ for Prochlorococcus MED4, the decrease in $F_{\mathrm{v}} / F_{\mathrm{m}}$ was $>90 \%$ for Synechococcus WH8102 (Fig. 2). In Synechococcus WH8102 Replicates B and C, the decrease in $F_{\mathrm{v}} / F_{\mathrm{m}}$ was driven by a $70 \%$ increase in $F_{0}$, from $577 \pm$ 66 to $984 \pm 46$ (Fig. 2B). In these replicates, $F_{\mathrm{m}}$ under HL was indistinguishable from $F_{0}$. In Replicate A, $F_{0}$ increased $31 \%$ from 550 to 723 , but $F_{\mathrm{m}}$ also decreased slightly from 810 to 749 (Fig. 2B). While $F_{0}$ increased in Prochlorococcus MED4 under HL compared to LL (approximately 50\%), it remained much lower than in Synechococcus WH8102 (Fig. 2B). Despite the very slight variable fluorescence in HL-exposed Synechococcus WH8102, carbon fixation and growth remained relatively high (Fig. 3). 
Table 1. Primers used for quantitative reverse transcriptase polymerase chain reaction (qRT-PCR) analysis of transcript levels in Synechococcus WH8102 (designated SYNW) and Prochlorococcus MED4 (designated PMM)

\begin{tabular}{|c|c|c|c|c|}
\hline Putative function & $\begin{array}{l}\text { Gene } \\
\text { identifier }\end{array}$ & $\begin{array}{l}\text { Gene } \\
\text { name }\end{array}$ & Forward primer & Reverse primer \\
\hline $\begin{array}{l}\text { Ammonium } \\
\text { transport }\end{array}$ & $\begin{array}{l}\text { SYNW0253 } \\
\text { PMM0263 }\end{array}$ & $\begin{array}{l}a m t 1 \\
a m t 1\end{array}$ & $\begin{array}{l}\text { CCT GGT TCC CAC TGT TGA TT } \\
\text { CAC GCA GCT GAT TTA CCT GA }\end{array}$ & $\begin{array}{l}\text { CTG CCT GCA ACA GGG TAA AT } \\
\text { ATC CGT CAG CAA CAC TTC CT }\end{array}$ \\
\hline $\begin{array}{l}\text { Urea } \\
\text { transport }\end{array}$ & $\begin{array}{l}\text { SYNW2441 } \\
\text { PMM0970 }\end{array}$ & $\begin{array}{l}\operatorname{urtB} \\
\operatorname{urt} A\end{array}$ & $\begin{array}{l}\text { GAC GTG GTT CCT CAA CAA A } \\
\text { TAC TGC CTC TCT TGC CGT TT }\end{array}$ & $\begin{array}{l}\text { CCG AGT AGG GAG ACT GCA AC } \\
\text { GCT TTT TCC ACC AAC GGT TA }\end{array}$ \\
\hline Nitrate transport & SYNW2463 & $n r t P$ & CGA TCC TCG AGC TCA CCT AC & CAT GCT CAT CAC CAG GTA GCC \\
\hline $\begin{array}{l}\text { Rubisco large } \\
\text { subunit }\end{array}$ & $\begin{array}{l}\text { SYNW1718 } \\
\text { PMM0550 }\end{array}$ & $\begin{array}{l}r b c L \\
r b c L\end{array}$ & $\begin{array}{l}\text { GTC TGG AAG ACA TCC GCT TC } \\
\text { CGA TTT GAG TTC GTT GCT G }\end{array}$ & $\begin{array}{l}\text { GTC CTT GGT GAA GTC CAG ACC } \\
\text { CCA GTT TGC AAG GCC AGT AT }\end{array}$ \\
\hline $\begin{array}{l}\text { PSII apoprotein } \\
\text { D1:1 }\end{array}$ & SYNW1470 & $p s b A-1$ & GGG AAG CTT TTT GTC AGT GG & CAC CGG AGA TGA TGT TGT TG \\
\hline $\begin{array}{l}\text { PSII apoprotein } \\
\text { D1:2 }\end{array}$ & $\begin{array}{l}\text { SYNW0983 } \\
\text { SYNW2151 } \\
\text { SYNW1919 }\end{array}$ & $\begin{array}{l}p s b A-2 \\
p s b A-3 \\
p s b A-4\end{array}$ & $\begin{array}{l}\text { CTC CAC CAA CAA CCG TCT TT } \\
\text { CAA GTT TGG CCA AGA GGA AG }\end{array}$ & CAT TGC TGG AAG GAA CAA CA \\
\hline PSII apoprotein D1 & PMM0223 & $p s b A$ & ACC AGT TGC TGG TTC ATT CC & CAC TGA CGT CCC ATG TAT GC \\
\hline $\begin{array}{l}\text { PSII chl a-binding } \\
\text { protein CP47 }\end{array}$ & $\begin{array}{l}\text { SYNW1982 } \\
\text { PMM0315 }\end{array}$ & $\begin{array}{l}p s b B \\
p s b B\end{array}$ & $\begin{array}{l}\text { GAG TCC ATC CCT GAA AAG C } \\
\text { CTG GAG CTT CGA AGG TGT TG }\end{array}$ & $\begin{array}{l}\text { CGA CAG GGA AGT TCT CGA AG } \\
\text { GAA AAG CTC CAA ATC CAA AGC }\end{array}$ \\
\hline $\begin{array}{l}\text { PSII chl a-binding } \\
\text { protein CP43 }\end{array}$ & $\begin{array}{l}\text { SYNW0676 } \\
\text { PMM1158 }\end{array}$ & $\begin{array}{l}p s b C \\
p s b C\end{array}$ & $\begin{array}{l}\text { CGC TCT CTA ATC CCG GTC } \\
\text { GGC CCA AAG CTT TAC TTT CC }\end{array}$ & $\begin{array}{l}\text { CGT ACA TGG GTT TGT CGA AG } \\
\text { CAA GGC TCA ATC CGT TAG G }\end{array}$ \\
\hline PSI apoprotein & SYNW2124 & $\operatorname{psa} A$ & ACC TGC TGG CAC AGC TCT ATC & GTA CAT GTG ACC AGC GAC GAT G \\
\hline PSI apoprotein & PMM1524 & $\operatorname{psa} A$ & TAT GGG CCC AAT CTT CTC AG & CTT GGT TGA ATT GTT GGA GC \\
\hline $\begin{array}{l}\text { Light-harvesting } \\
\text { complex protein }\end{array}$ & PMM0627 & $p c b$ & CCG GTG CTT TCA CTC TTT TC & ATC CAC CAG CTG CAA GTA CC \\
\hline $\begin{array}{l}\text { Allophycocyanin } \\
\text { beta chain }\end{array}$ & SYNW0484 & apcB & GCC AAG GCT CTG CTG TAC TC & CAC ACC CAG GGA GTT GTA GG \\
\hline $\begin{array}{l}\text { Phycocyanin II } \\
\text { beta chain }\end{array}$ & SYNW2022 & $r p c B$ & CGC GAC ATG GAG ATC ATT C & GCG GAA ATA CCA GCT TTG TC \\
\hline $\begin{array}{l}\text { Phycoerythrin I } \\
\text { beta chain }\end{array}$ & SYNW2017 & среB & CGC TAG CCT CCG TTC TTA TG & GCG AAG AAC GAT CTC ACC ATC \\
\hline $\begin{array}{l}\text { Plastid terminal } \\
\text { oxidase }\end{array}$ & $\begin{array}{l}\text { SYNW0887 } \\
\text { PMM0336 }\end{array}$ & $\begin{array}{l}\text { ptox } \\
\text { ptox }\end{array}$ & $\begin{array}{l}\text { CGA GGC AGT CAA GAC GTA CA } \\
\text { GCA AGG TCT CCT TAT TTT GC }\end{array}$ & $\begin{array}{l}\text { GCT ATT GGC TTT GAC GTG GT } \\
\text { GGT GCC TTG CTA AAA ACC TG }\end{array}$ \\
\hline $\begin{array}{l}\text { High-light } \\
\text { inducible protein }\end{array}$ & $\begin{array}{l}\text { SYNW1449 } \\
\text { SYNW0330 } \\
\text { SYNW0616 } \\
\text { SYNW0817 } \\
\text { SYNW2403 } \\
\text { SYNW2180 } \\
\text { SYNW1331 } \\
\text { SYNW1833 } \\
\text { PMM1118 } \\
\text { PMM1404 } \\
\text { PMM1398 } \\
\text { PMM1396 } \\
\text { PMM1385 } \\
\text { PMM1384 } \\
\text { PMM0816 } \\
\text { PMM0690 }\end{array}$ & $\begin{array}{l}\text { hli1 } \\
\text { hli2 } \\
\text { hli3 } \\
\text { hli4 } \\
\text { hli5 } \\
\text { hli6 } \\
\text { hli7 } \\
\text { hli8 } \\
\text { hli4 } \\
\text { hli5 } \\
\text { hli7 } \\
\text { hli9 } \\
\text { hli11 } \\
\text { hli12 } \\
\text { hli18 } \\
\text { hli21 }\end{array}$ & $\begin{array}{l}\text { GAC TCC GCC TCC AAG ACT C } \\
\text { GCT TTT GGC TGG AGT GGT TAC } \\
\text { GCT TGA GCC CAC TGA CAT C } \\
\text { GAC TCC TTC CAC CGA TGC } \\
\text { CAA CTC AAA AGG GGC AAT CAG } \\
\text { GTC TGA CAA CGC ACG CTT C } \\
\text { GGC TTT CCA GTA CGA GCA AC } \\
\text { GGC TGA GCA ACT CGA AAA G } \\
\text { GTT TTA ATG GTT GGG CAG CA } \\
\text { CGA AAC AAA AAC AGT TGA GAA GG } \\
\text { GAG TCT GGC GGA AGA CAA AA } \\
\text { CTG GCA AAA TGC AGA AAG AA } \\
\text { ATG AAG AAC AAC GAA CCA AAA } \\
\text { GTT TTA ATG GTT GGG CAG CA } \\
\text { GCT TTA CTC GTT GCT TCC CTAA } \\
\text { GGC AAA AAT CAA ATC TGT TGA A }\end{array}$ & $\begin{array}{l}\text { GCA ATC CGA AGC CGA TCT G } \\
\text { CCA ATG CAG GAA GGT GTC TC } \\
\text { CAC CAG ATC AGC AGA CCA TG } \\
\text { CAG TTT TTC AGC CCG TTC } \\
\text { CTT CGG TGA TGA TCC CAA TC } \\
\text { CCG ATC TGG GAC AGG ATG } \\
\text { CCC AGT TCG AGA TAC CAA CG } \\
\text { CAG TTC CCG GCA AAC AC } \\
\text { GAA CCA ACC TGG AAT GAT TTG } \\
\text { CGA ATC CAG GAA TAA TTT GAC C } \\
\text { CCT GGA ATG ATT TGA CCT GTT } \\
\text { CCC AGG TAT GAT CCA GCC } \\
\text { CCA GGA ATA ATT TGA CCT GTG G } \\
\text { CCA ACC AGG GAT GAT TTG AC } \\
\text { CGA AAC CTG GAA TGA TTT GA } \\
\text { CGA ATC CAG GAA TAA TTT GAC C }\end{array}$ \\
\hline $\begin{array}{l}\text { Protoporphyrin } \\
\text { chelatase subunit }\end{array}$ & $\begin{array}{l}\text { SYNW0716 } \\
\text { PMM1055 }\end{array}$ & $\begin{array}{l}\text { chli } \\
\text { chlI }\end{array}$ & $\begin{array}{l}\text { GAT CCT GAA CTA CGG GTC C } \\
\text { GGC CTT TGA ACC AGG CTT AT }\end{array}$ & $\begin{array}{l}\text { GTC CAT CCA CAT CCA GCT C } \\
\text { CTC TTC TGG ATT GCC AGA GC }\end{array}$ \\
\hline $\begin{array}{l}\text { Chlorophyll } \\
\text { synthase subunit }\end{array}$ & PMM0428 & chlG & GAG CGG ACC ACT TTT AGC AG & CCC ACC TAA AGC CAG AAG AA \\
\hline $\begin{array}{l}\text { Low-light } \\
\text { inducible protein }\end{array}$ & SYNW0667 & $\operatorname{irt} A$ & GAG GGA CTA CAC CCA GAC C & GAT GCT GGC GTA CAG GTT C \\
\hline
\end{tabular}




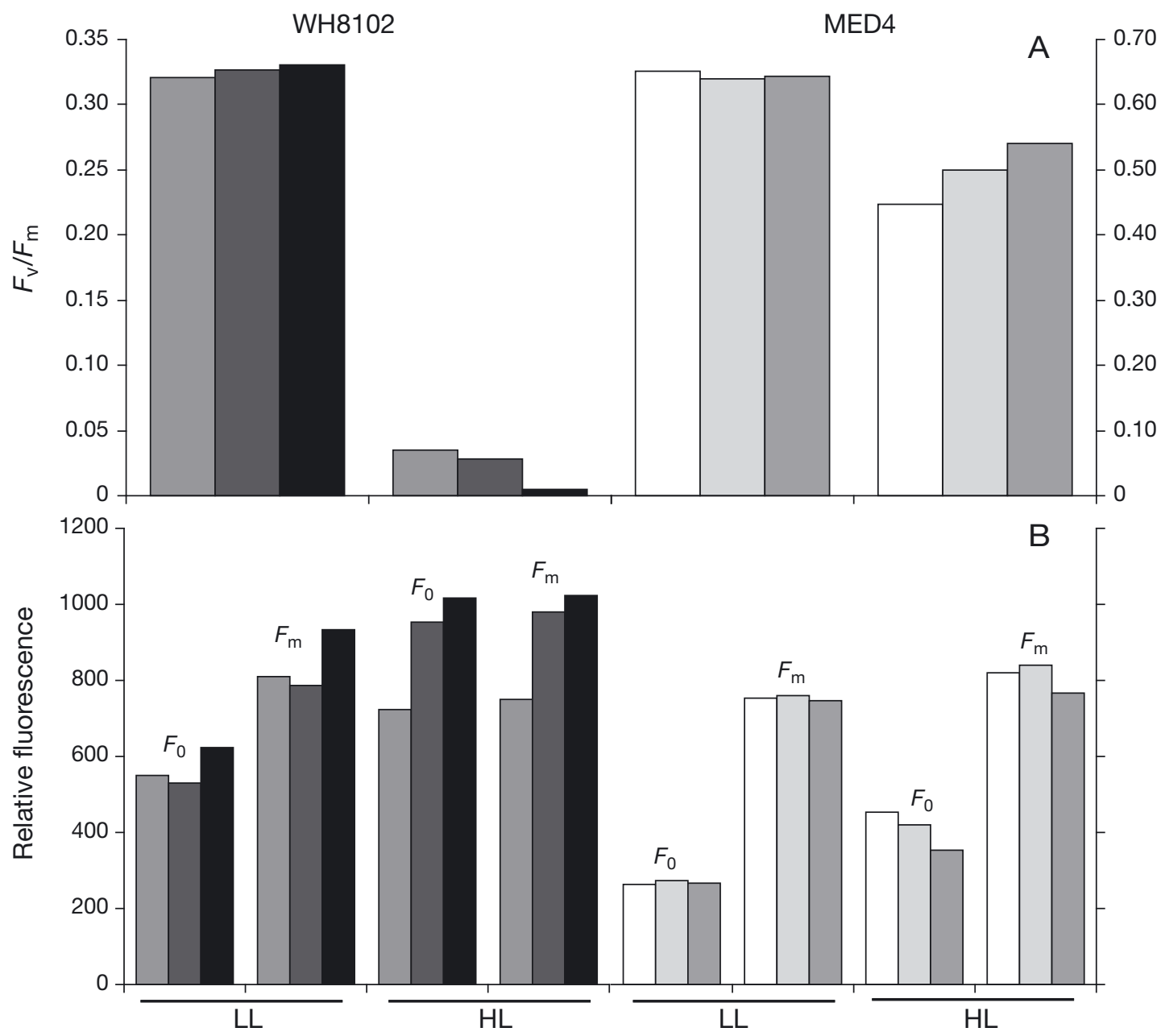

Fig. 2. Fluorescence characteristics of Synechococcus WH8102 and Prochlorococcus MED4. (A) Photosynthetic efficiency $\left(F_{\mathrm{v}} / F_{\mathrm{m}}\right)$ of triplicate Synechococcus WH8102 (grey, dark grey and black bars) and Prochlorococcus MED4 (white, light grey and grey bars) grown under low-light (LL) and high-light (HL) conditions. (B) $F_{0}$ and $F_{\mathrm{m}}$ : fluorescence of triplicate Synechococcus WH8102 (grey, dark grey and black bars) and Prochlorococcus MED4 (white, light grey and grey bars) grown under low-light (LL) and high-light (HL) conditions

\section{Carbon fixation}

Although the $P_{\max }^{*}$ in Prochlorococcus MED4 was 3-fold greater under HL than under LL (Fig. 3A), there was no difference in $\alpha^{*}$ between the 2 light treatments (Table 2). In contrast, $P_{\max }^{*}$ and $\alpha^{*}$ for Synechococcus WH8102 were $>2$-fold and 5 -fold higher, respectively, in the LL treatment than in the HL treatment (Fig. 3B, Table 2). Under LL, $P_{\max }^{*}$ was 5-fold greater in Synechococcus WH8102 than in Prochlorococcus MED4. Under HL, $P_{\max }^{*}$ was nearly the same for Synechococcus WH8102 and Prochlorococcus MED4 (Fig. 3, Table 2). Interestingly, both taxa displayed similar $E_{\mathrm{k}}$ values for growth under HL (124 to $174 \mu \mathrm{mol}$ photons $\mathrm{m}^{-2} \mathrm{~s}^{-1}$ ) and LL (52 to $54 \mu \mathrm{mol}$ photons $\mathrm{m}^{-2} \mathrm{~s}^{-1}$ ) conditions (Table 2).
Table 2. Photosynthesis-irradiance variables. $P_{\max }^{*}=$ the maximum chl a-normalized rate of carbon fixation $\left(\mu \mathrm{g} \mathrm{C} \mu \mathrm{g}^{-1}\right.$ chl $\left.a \mathrm{~h}^{-1}\right) ; \alpha^{*}=$ the chl $a$-normalized initial slope of the photosynthesis-irradiance (P-E) curve, an index of photosynthetic

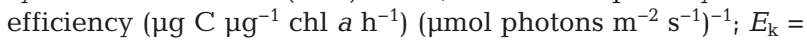
the irradiance at which photosynthesis approaches saturation, an index of photoacclimation $\left(P_{\max }^{*} / \alpha^{*}, \mu \mathrm{mol}\right.$ photons $\left.\mathrm{m}^{-2} \mathrm{~s}^{-1}\right)$. WH8102 = Synechococcus WH8102; MED4 = Prochlorococcus MED4; HL: high light; LL: low light

\begin{tabular}{|lccc|}
\hline Parameter & Organism & HL & LL \\
\hline$P_{\max }^{*}$ & WH8102 & 2.11 & 4.3 \\
$\alpha^{*}$ & MED4 & 2.44 & 0.84 \\
& WH8102 & 0.017 & 0.08 \\
$E_{\mathrm{k}}$ & MED4 & 0.014 & 0.016 \\
& WH8102 & 124 & 54 \\
& MED4 & 174 & 52 \\
\hline
\end{tabular}




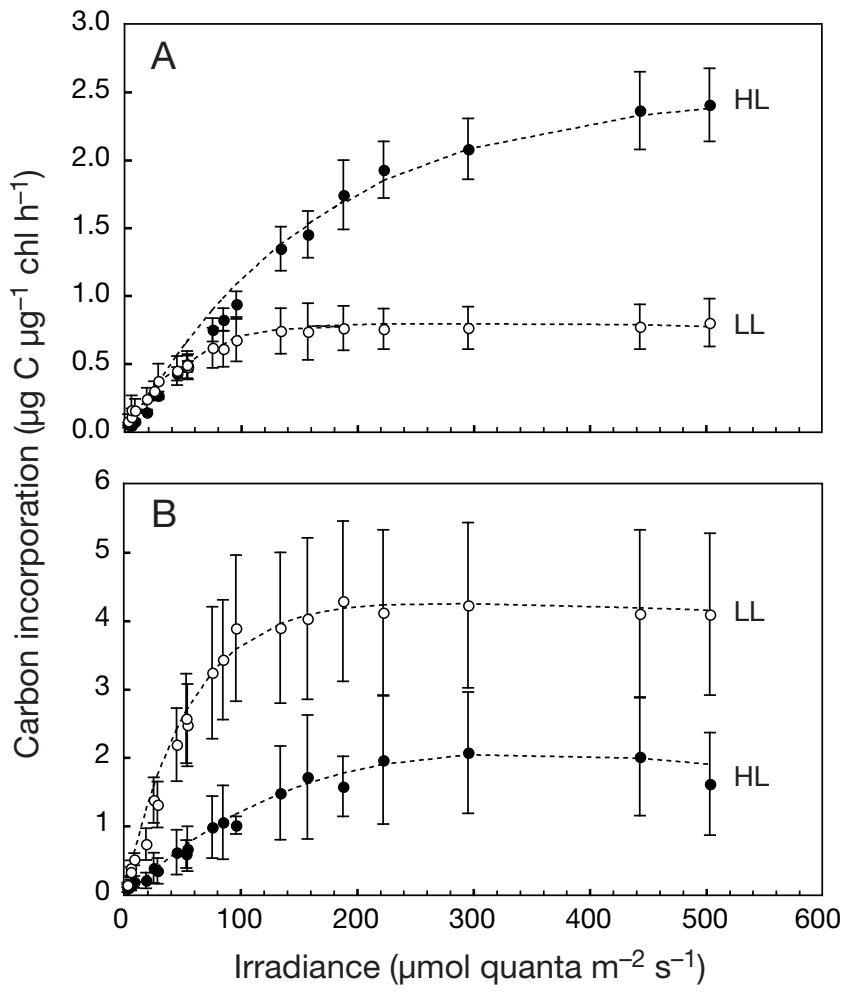

Fig. 3. Carbon fixation of (A) Prochlorococcus MED4 and (B) Synechococcus WH8102 under low-light (LL, O) and highlight $(\mathrm{HL}, 0)$ treatments. Means $\pm \mathrm{SD}$ of triplicate cultures are shown

\section{Relative transcript abundance $\left(\Delta C_{t}\right)$}

Based on preliminary results we identified a number of genes involved in photosynthesis and the HLIPs (data not shown) that were differentially regulated under HL. For example, we identified 8 hli genes out of the 22 present in Prochlorococcus MED4 that were upregulated under HL compared to LL. In addition to these genes, we assayed the expression of genes encoding PSI and PSII reaction center proteins, light-harvesting proteins and biliproteins, chl a synthesis proteins, and nitrogen transporters. We chose primers with similar priming efficiencies (see 'Materials and methods') to facilitate comparison of expression across genes. However, we also compared absolute transcript abundance, calculated from the slope of the standard curve (noted in parentheses), with $\Delta C_{t}$ in Fig. 4. The most abundant transcripts in LL-acclimated Prochlorococcus MED4 were amt1 (0.0105 $\pm 0.001 \mathrm{ng}$ mRNA $\mu^{-1}$ TRNA) encoding the ammonium transporter, $p c b(0.0110 \pm 0.008$ ng mRNA $\mu g^{-1}$ TRNA) encoding the light-harvesting antenna protein, and psbA $(0.0098 \pm 0.0009 \mathrm{ng}$ mRNA $\mu \mathrm{g}^{-1}$ TRNA) encoding the PSII reaction center protein D1 (Fig. 4A). Other transcripts that accumulated to high levels were ptox $\left(0.00062 \pm 0.0002 \mathrm{ng}\right.$ mRNA $\mu^{-1}$
TRNA) encoding the plastid terminal oxidase, and $r b c L$ $\left(0.0002 \pm 0.00003 \mathrm{ng}\right.$ mRNA $\mu g^{-1}$ TRNA) encoding Rubisco (Fig. 4A). In relative terms, the hli genes comprised the least expressed of the genes we assayed (Fig. 4A). Similar to Prochlorococcus MED4, the most abundant transcript in Synechococcus WH8102 under LL was amt1 $(0.0117 \pm 0.005)$. However, the second most abundant transcript was rbcL $(0.0042 \pm 0.0004)$, followed by $p s b A 3 / 4(0.0032 \pm 0.001)$ and psaA $(0.0016 \pm 0.0003)$, the latter encoding the PSI reaction center protein (Fig. 4B). The abundance of the ptox transcript in Synechococcus WH8102 was relatively low (0.00005 \pm $0.000008)$, similar to the levels measured for the hli transcripts (Fig. 4B).

\section{Transcript induction $\left(\Delta \Delta C_{t}\right) \mathrm{HL} / \mathrm{LL}$}

Here we define the term induction as the fold difference in relative transcript abundance in HL-acclimated over LL-acclimated cells. Transcripts from genes encoding proteins involved in $\mathrm{N}$ uptake, $\mathrm{C}$ fixation, and chl a synthesis were either not induced or were depressed in both species (Fig. 5A). A notable exception was $n r t P$, encoding the nitrate transporter in Synechococcus WH8102, which was induced 4 -fold (Fig. 5A). Transcripts from the chl a synthesis genes chll and chlG were depressed, as was the transcript from the LL inducible gene irt $A$, which was 2-fold depressed in Prochlorococcus MED4 and 5-fold depressed in Synechococcus WH8102 (Fig. 5A). Although no physiological function has been assigned to the IrtA protein, the gene has been shown to be induced under LL (relative to HL) in Prochlorococcus sp. and, as such, was used here as a negative control. In both species, the $r b c L$ transcript was depressed under HL. However, it was significantly more depressed in Synechococcus WH8102 (17-fold) compared with Prochlorococcus MED4 (3.5-fold), consistent with changes in $P_{\max }^{*}$ (Fig. 3, Table 2).

In Prochlorococcus MED4, the hli gene transcripts assayed here were induced 4 - to 14 -fold, and the 4 most highly induced were hli7 (14 \pm 2$)$, hli18 (13 \pm 4$)$, hlig (11 $\pm 10)$ and hli5 $(7 \pm 6)$. In Synechococcus WH8102, the most highly induced hli gene transcripts were hli6 (5 \pm 2$)$, hli4 (4 \pm 1$)$, hli1 $(3 \pm 0.3)$ and hli5 ( $2 \pm 0.3)$ (Fig. 5B). Average induction for the 4 most highly induced hli gene transcripts was 11-fold in Prochlorococcus MED4 and 3.5-fold in Synechococcus WH8102. Not all the hli gene transcripts were induced under HL in Synechococcus WH8102; hli8 and hli2 were depressed 1.5-fold whereas the levels of hli3 and hlif transcripts did not vary between LL and HL (Fig. 5B). The ptox gene transcript was induced $2.5 \pm 1.3$ in Prochlorococcus MED4 and depressed 2.5-fold in Synechococcus WH8102 (Fig. 5B). 


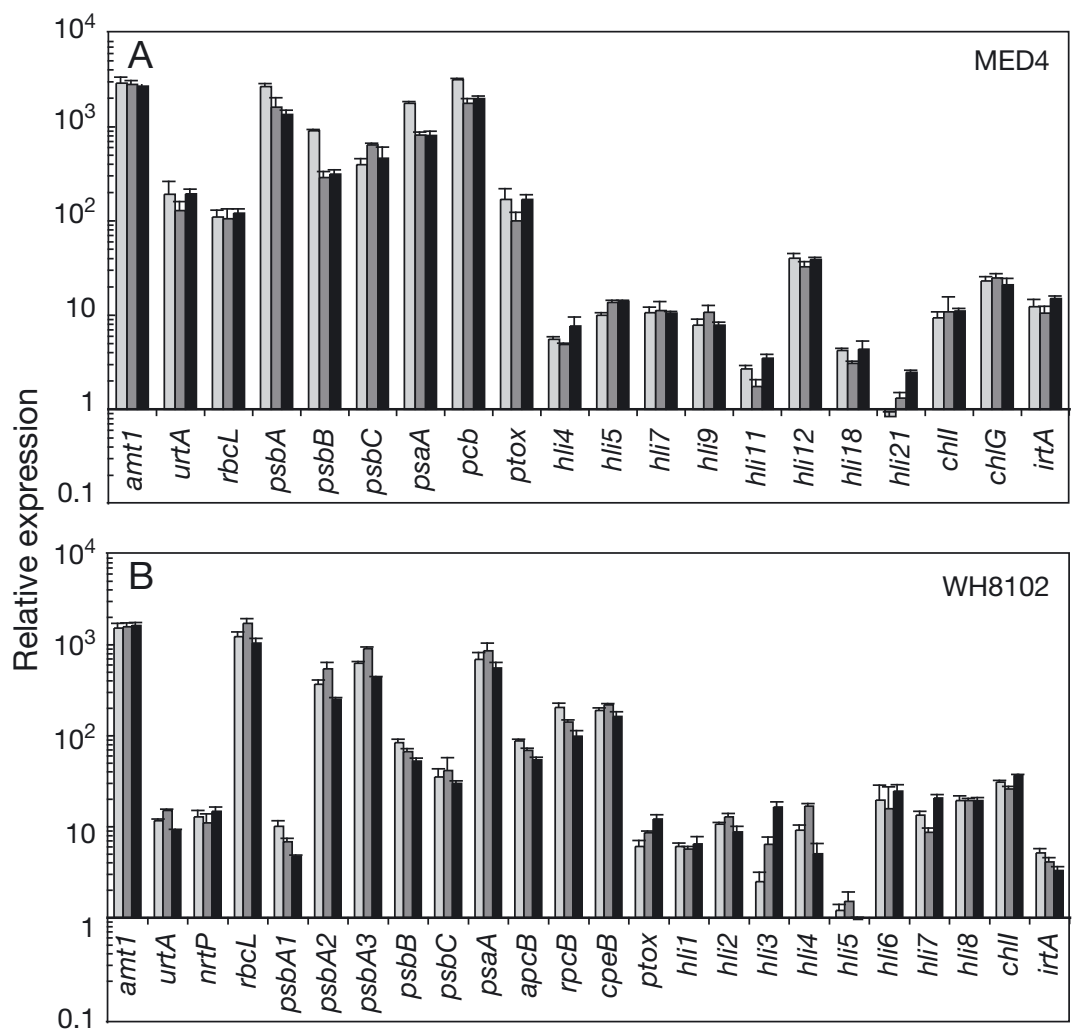

Fig. 4. Relative log expression $\left(\Delta C_{t}\right)$ of transcripts associated with nitrogen uptake (amt1, urtA, nrtP), carbon fixation $(r b c L)$, photosynthetic reaction centers (psbA, psbB, psbC, psaA), light harvesting $(p c b, a p c B, r p c B, c p e B)$, excess energy dissipation (ptox , hli), chlorophyll synthesis (chll, chlG) and low light (irtA) in (A) Prochlorococcus MED4 and (B) Synechococcus WH8102 grown under low-light (LL) conditions. Duplicate measurements (+SD) for each of 3 cultures (shaded light grey, grey, black) are shown. Transcript psbA3/4 has been abbreviated to $p s b A 3$

\section{Synechococcus WH8102 psbA composition}

The differential induction of the $p s b A$ gene transcripts in Synechococcus WH8102 resulted in a change in the composition of the total $p s b A$ transcript pool between the LL and HL treatments. Under LL, psbA3/4 contributed $80 \%$, psbA2 contributed $17 \%$, and psbA1 contributed $3 \%$ of total psbA transcript abundance (Fig. 6). Whereas the contribution of $p s b A 3 / 4$ remained at $80 \%$ under $\mathrm{HL}$, the $p s b A 2$ contribution decreased to $1 \%$ and the contribution of psbA1 increased to $18 \%$ of total psbA transcript abundance under HL (Fig. 6).

\section{DISCUSSION}

Changes in the relative transcript abundances of the psbA, hli and ptox gene families in response to increased irradiance differed significantly between Synechococcus WH8102 and Prochlorococcus MED4. Our results suggest that the regulation of these gene families, and in some cases their functions, also varies between these 2 cyanobacterial species.
Compared with the induction of the hli gene transcripts, the induction of the gene transcripts encoding the reaction center proteins was low in Prochlorococcus MED4. Only $p s b A$, which encodes the D1:1 isoform, was induced $(2.5 \pm 0.5)$. In contrast, $p s b A 2$ (encoding D1:2) was significantly induced (60 \pm 5 ) in Synechococcus WH8102 followed by psbA3/4, also encoding D1:2 $(7 \pm 1)$. In contrast, $p s b A 1$, which encodes D1:1, was depressed 3-fold (Fig. 5C). Both psbB $(2 \pm 0.1)$ and psbC $(8 \pm 1)$ genes, encoding the CP47 and CP43 chlorophyllbinding proteins, respectively, were induced in Synechococcus WH8102. In contrast, psbB was depressed 2.6 -fold and $p \operatorname{sbC}(1.5 \pm 0.3)$ was not significantly regulated in Prochlorococcus MED4 (Fig. 5C). In both species, psaA (encoding the PSI reaction center apoprotein) was depressed (Fig. 5C) while in Prochlorococcus MED4, $p c b$ (encoding the light-harvesting antenna proteins) was slightly depressed. There was no change in the $a p c B, r p c B$ and $c p e B$ genes encoding the biliproteins allophycocyanin, phycocyanin and phycoerythrin, respectively, in Synechococcus WH8102 (Fig. 5C).

\section{$p s b A$ transcript induction and photoinhibition}

HL-acclimated Prochlorococcus MED4 cultures recovered their $F_{\mathrm{v}} / F_{\mathrm{m}}$ to near maximum following an 8fold shift in light intensity after a short period of acclimation. In contrast, a $>90 \%$ reduction in PSII photochemical efficiency in Synechococcus WH8102 cultures following a 3-fold shift in light intensity suggested that they were severely photoinhibited. In the latter cultures, the individual $p s b A$ transcripts exhibited marked changes in abundance between LL and HL. Following exposure of cells to HL, the D1:1 isoform encoded by psbA1 declined, while the D1:2 isoform encoded by psbA2-4 increased 7- to 60-fold. In freshwater Synechococcus PCC 7942, an increase in D1:2 transcription and D1:2 polypeptide composition of the PSII reaction center is associated with greater resistance to photoinhibition through improved dissipation of excess absorbed light energy (Schaefer \& Golden 1989a, Krupa et al. 1991, Clarke et al. 1993, Campbell et al. 1996). Unlike the situation in freshwater Synechococcus 


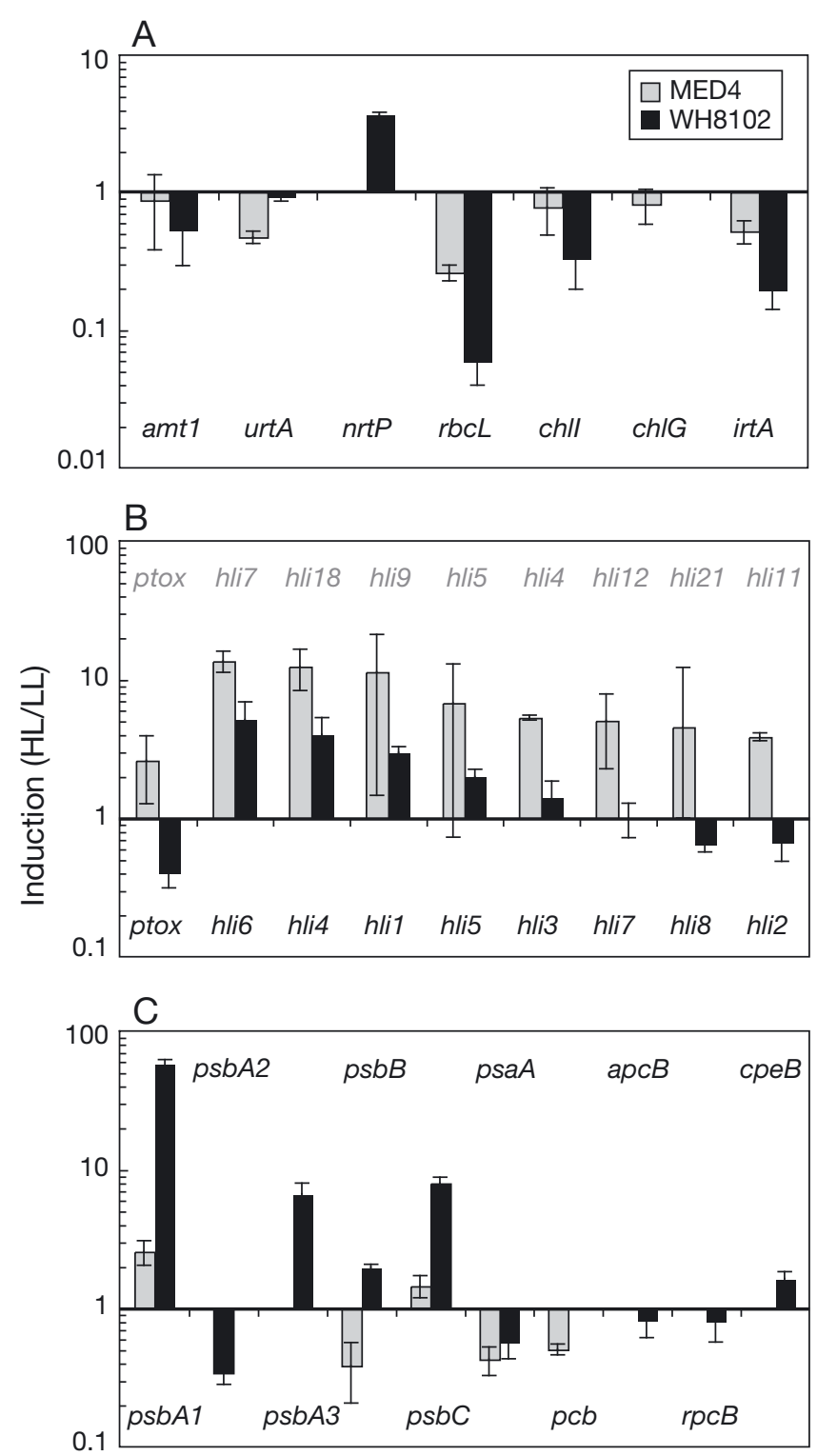

Fig. 5. Induction (comparative relative expression, $\Delta \Delta C_{t}$, high light (HL)/low light (LL)) of transcripts associated with (A) nitrogen uptake (amt1, urtA, nrtP), carbon fixation $(r b c L)$, chlorophyll synthesis (chll, chlG) and low light (irtA); (B) excess energy dissipation (ptox, hli); and (C) photosynthetic reaction centers ( $p s b A, p s b B, p s b C, p s a A)$ and light harvesting $(p c b, a p c B, r p c B, c p e B)$ in Prochlorococcus MED4 and Synechococcus WH8102. Means \pm SD of triplicate cultures are shown

PCC 7942, PSII photochemical efficiency does not appear to be restored by increased transcription of D1:2 polypeptide in marine Synechococcus WH8102 or in Synechococcus WH7803 (Six et al. 2007a, Garczarek et al. 2008). In both of these marine species, the $F_{\mathrm{v}} / F_{\mathrm{m}}$ remains depressed despite substantial increases in $p s b A$ mRNA following HL and UV treatments (Six et al. 2007a, Garczarek et al. 2008). Potential explanations for

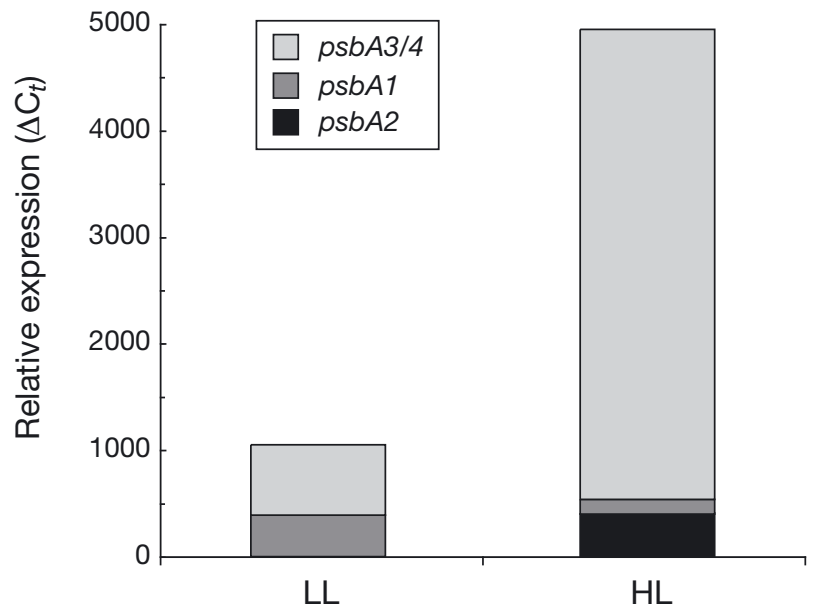

Fig. 6. Absolute changes in the psbA gene pool in Synechococcus WH8102 grown under low-light (LL) and highlight (HL) conditions

this include the fact that either damaged D1 proteins are not being replaced rapidly enough to overcome photodamage (Six et al. 2007a), or a high level of intracellular oxidative stress elicits damage of newly synthesized D1:2 proteins before they have had a chance to substitute the damaged D1:1 proteins in the reaction center (Garczarek et al. 2008).

If most D1 proteins in PSII were non-functional, resulting in an $F_{\mathrm{v}} / F_{\mathrm{m}}$ approaching zero, we would expect that most cells would be unable to perform photosynthesis and rapidly lose viability. Contrary to this expectation, HL-acclimated Synechococcus WH8102 cultures continued to grow fairly well despite their severely reduced $F_{\mathrm{v}} / F_{\mathrm{m}}$. This finding may be explained by factors that serve to depress $F_{\mathrm{v}} / F_{\mathrm{m}}$ independently of PSII damage. As mentioned previously, $F_{\mathrm{v}} / F_{\mathrm{m}}$ is not directly comparable between species that have a PBS light-harvesting system and those that have a chlorophyll-based antenna. One reason for this is that the PBS contributes to $F_{0}$ fluorescence, thereby decreasing the amount of variable fluorescence and the value of $F_{\mathrm{v}} / F_{\mathrm{m}}$. Therefore, it is important to determine whether a decrease in $F_{\mathrm{v}} / F_{\mathrm{m}}$ in Synechococcus is caused by a decrease in $F_{\mathrm{m}}$ an increase in $F_{0}$, or both. As noted in Fig. 2B, the decrease in $F_{\mathrm{v}} / F_{\mathrm{m}}$ in HL-acclimated Synechococcus WH8102 was driven mostly by an increase in $F_{0}$, in striking contrast to the situation for Prochlorococcus MED4, suggesting that the decrease in $F_{\mathrm{v}} / F_{\mathrm{m}}$ resulted from an increase in PBS fluorescence. Such an increase could result from a decoupling of PBS subcomplexes from the thylakoid membranes, potentially reducing the transfer of energy from the PBS to the PSII reaction center, thereby elevating fluorescence emissions. Six et al. (2007a) suggested - on the basis of degradation of the $\mathrm{L}_{\mathrm{CM}}$ linker polypeptide (large chromophorylated protein that an- 
chors the PBS to the thylakoid membrane) - that a large number of PBS units become disconnected from the membranes following exposure of Synechococcus WH8102 to UV irradiation. These authors also suggested that the release of highly fluorescent phycobiliproteins in the cytosol constitutes a photoprotective mechanism that may prevent excess photons from reaching PSII. As such, PBS uncoupling and the ensuing increase in $F_{0}$ fluorescence may mask the functionality of the PSII reaction center by depressing $F_{\mathrm{v}} / F_{\mathrm{m}}$ in a manner that is not proportional to D1 damage.

While changes in $F_{\mathrm{v}} / F_{\mathrm{m}}$ do not appear proportional to PSII damage in Synechococcus WH8102, elevated psbA transcript abundance coupled with a 2-fold decrease in $P_{\max }^{*}$ and a 5 -fold reduction in $\alpha^{*}$ indicated that the HL-acclimated Synechococcus WH8102 cultures were suffering from D1 photodamage (cf. Behrenfeld et al. 1998). Our results also indicated that Synechococcus WH8102 can acclimatize to, and grow under, conditions that lead to persistent photoinhibition. However, it is still unclear why Synechococcus WH8102 was not able to recover fully from photoinhibition. Perhaps the answer lies in the efficiency with which the light-harvesting antennae funnel excitation energy to the PSII reaction center. Photoinhibition can result from even moderate light exposure if excess light-harvesting antennae are present relative to chl $a$. For example, in Synechococcus PCC 7942 the extent of photoinhibition following a light shift depends, in a linear fashion, on the ratio antennae pigment:chl $a$ (Clarke et al. 1995). Because the amount of pigment is, to a large extent, dictated by concentrations of external nitrogen (N) (Yamanaka \& Glazer 1980, Wyman et al. 1985, Glibert et al. 1986, Collier \& Grossman 1992), shifting marine Synechococcus grown under N-sufficient conditions from low to high light may result in a degree of photodamage that the cells cannot recover from due to the large ratio of antennae pigment to chl $a$ existing in the cells prior to the light shift. In nature, conditions of high nutrients and high irradiance very seldom co-occur, and cyanobacteria in the upper layers of the oligotrophic ocean potentially never develop large antennae pigment:chl $a$ ratios.

\section{hli transcript induction and photoprotection}

In addition to the efficient transfer of excitation energy by the PBS to the PSII reaction center, the ease with which Synechococcus WH8102 cultures became photoinhibited relative to Prochlorococcus MED4 cultures may be related to differences in their respective strategies of photoprotection, potentially driven by differences in hli transcript induction. On average, hli transcript induction was 5 -fold greater in HL-accli- mated Prochlorococcus MED4 than in HL-acclimated Synechococcus WH8102. The genes associated with the 3 most upregulated transcripts (hli7, hli18 and hli9) belong in the hli6-9 and hli16-19 operons in the Prochlorococcus MED4 genome (Bhaya et al. 2002). Of all the Prochlorococcus MED4 hli genes, the genes in these 2 operons have been reported to be the most responsive to shifts in light intensity (Steglich et al. 2006). Expression of hli5 and hli4 also increased significantly, consistent with earlier observations by Steglich et al. (2006). We did not survey the levels of hli1, hli2, hli10, hli13 and hli20 transcripts because preliminary tests suggested that light intensity did not significantly alter their expression. In an investigation by Steglich et al. (2006), the levels of transcripts from these genes were similar under all light treatments, suggesting that factors other than light may regulate expression of these genes. In contrast to Prochlorococcus MED4, only 2 hli genes (hli6 and hli4) were induced to a significant extent in HL-acclimated Synechococcus WH8102. If the hli genes do encode proteins that dissipate excess light energy (He et al. 2001, Havaux et al. 2003), then this result is surprising because all genes encoding proteins involved in excess energy dissipation would be expected to increase under conditions of persistent photoinhibition. The difference in the number of hli genes that were induced in Synechococcus WH8102 and Prochlorococcus MED4, and the extent to which they were induced in response to growth at higher irradiance, suggests that a greater number of the HLIPs are involved in excess energy dissipation and photoprotection in Prochlorococcus MED4 than in Synechococcus WH8102. However, translational regulation of HLIP activity may or may not be related to transcription such that greater transcriptional HLIP regulation in Synechococcus WH8102 may make up for the decreased transcription compared with Prochlorococcus MED4.

\section{ptox transcript abundance and excess energy dissipation}

PTOX represents another putative pathway for dissipating excess absorbed excitation energy (Bailey et al. 2008). Based on the differences in transcript levels measured in this study, the ptox gene appears to be more active in Prochlorococcus MED4 than in Synechococcus WH8102; in the former, the basal ptox transcript level under LL was on par with that of $r b c L$, and it increased in the HL-acclimated cultures, suggesting that irradiance plays a role in its expression. This is consistent with the results of Steglich et al (2006), who demonstrated a 3- to 4 -fold increase in ptox transcript levels in Prochlorococcus MED4 following exposure to light after a dark period. In contrast, ptox expression in 
Synechococcus WH8102 was barely detected in cells maintained under LL (150-fold lower than rbcL expression) and it decreased in the HL-acclimated cells; these results do raise questions about the function of PTOX in Synechococcus WH8102.

The interpretation of the role of PTOX is complicated by the fact that this oxidase is at the intersection of many redox pathways associated with the PQ pool. These pathways include oxidation of the PQ pool reduced by PSII (Shahbazi et al. 2007, Bailey et al. 2008), by NDH or other reductases (Bennoun 1982, Peltier et al. 1987, Bennoun 2002, Rumeau et al. 2007), and by phytoene desaturase, which is associated with the desaturation reactions of carotenoid biosynthesis (Wetzel et al. 1994, Carol et al. 1999, Josse et al. 2000, Kuntz 2004). It appears that the importance of PTOX in these various pathways differs among photosynthetic organisms. For example, in Arabidopsis, changes in PTOX expression and protein accumulation do not alter the redox state of the PQ pool and do not prevent photoinhibition (Rosso et al. 2006), as has been suggested for tomatoes and cyanobacteria (Shahbazi et al. 2007, Bailey et al. 2008). Rather than preventing PSII photoinhibition, it has been suggested that PTOX, in concert with $\mathrm{NDH}$, regulates cyclic electron flow around PSI by maintaining the redox state of the PQ pool in a manner that prevents PSI photoinhibition (Rumeau et al. 2007).

Most organisms that exhibit PTOX activity also synthesize carotenoids (Carol \& Kuntz 2001). If carotenoid synthesis is upregulated in HL-acclimated Prochlorococcus MED4 cultures, it may be difficult to distinguish the role of PTOX in re-oxidizing the PQ pool that has been reduced by PSII versus its role in the desaturation of phytoene, or other carotenoid synthesis reactions. It may well be that, in cyanobacteria, PTOX has a dual role (Shahbazi et al. 2007). To date, most investigations show that ptox is transcribed in the light, and that its transcription increases under increased irradiance (Simkin et al. 2003, Steglich et al. 2006). Because $\alpha$ carotene is an important pigment in Prochlorococcus MED4, and its cellular concentration is modulated by growth light intensity (Moore et al. 1995), the potential role of PTOX in the carotenoid synthesis pathway deserves closer examination.

Using $p s b A$ induction as a proxy for acclimation to changes in irradiance (cf. Clarke et al. 1993, Campbell et al. 1998b, Six et al. 2007a,b), we observed that the induction ratio of ptox:psbA1 and hli:psbA1 was 144 and 70 times greater, respectively, in Prochlorococcus MED4 than in Synechococcus WH8102 (Fig. 7). These observations suggest that induction of hli and ptox genes may help to alleviate excitation pressure in Prochlorococcus MED4 and reduce the need for $p s b A$ induction. In contrast, induction of $p s b A$ and synthesis

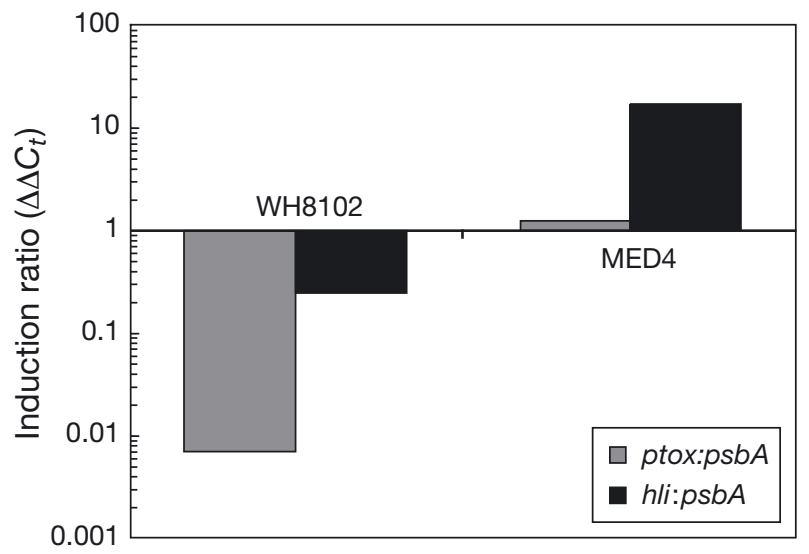

Fig. 7. Ratio of $\Delta \Delta C_{t}$ ptox: $\Delta \Delta C_{t} p s b A$ and $\Delta \Delta C_{t} h l i: \Delta \Delta C_{t} p s b A$ in Synechococcus WH8102 and Prochlorococcus MED4

of the PSII reaction center protein D1 may play a principal role in the acclimation of Synechococcus WH8102 to changes in irradiance, which may explain why cells experience photoinhibition and PBS uncoupling following a shift to higher growth light intensities (Six et al. 2004, 2007a).

In summary, it appears that the 2 cyanobacterial species investigated here have adapted different photoacclimation strategies to life in the oligotrophic ocean, raising the possibility that factors other than irradiance control the distribution of these phytoplankton in the water column. Synechococcus WH8102 appears optimized for high rates of carbon fixation and relies on synthesis and replacement of the PSII reaction center protein D1 as its primary mechanism of photoprotection. In contrast, Prochlorococcus MED4 appears to have evolved photoprotective strategies potentially involving energy dissipation via HLIP synthesis and via alternative electron flow to PTOX, although alternative electron flow to PTOX in Synechococcus WH8102 has also been noted (Bailey et al. 2008). Because both the hli and ptox gene families are present in these 2 species, but are regulated differently by irradiance, it is likely that the genes in these families have different functions in Synechococcus WH8102 and Prochlorococcus MED4.

Acknowledgements. This research was supported by NSF grant No. OCE-0450874 to A.R.G. and NSF grant No. OCE0450875 to K.R.A.

\section{LITERATURE CITED}

Arrigo KR, Mills MM, Kropuenske LR, Van Dijken GL, Alderkamp AC, Robinson DH (2010) Photophysiology in two major Southern Ocean phytoplankton taxa: photosynthesis and growth of Phaeocystis antarctica and Fragilariopsis cylindrus under different irradiance levels. Integr Comp Biol 50:950-966 
Bailey S, Melis A, Mackey KRM, Cardol P and others (2008) Alternative photosynthetic electron flow to oxygen in marine Synechococcus. Biochim Biophys Acta 1777:269-276

Behrenfeld MJ, Prasil O, Kolber ZS, Babin M, Falkowski PG (1998) Compensatory changes in photosystem II electron turnover rates protect photosynthesis from photoinhibition. Photosynth Res 58:259-268

Bennoun P (1982) Evidence for a respiratory chain in the chloroplast. Proc Natl Acad Sci USA 79:4352-4356

Bennoun P (2002) The present model for chlororespiration. Photosynth Res 73:273-277

- Berg GM, Shrager J, Glockner G, Arrigo KR, Grossman AR (2008) Understanding nitrogen limitation in Aureococcus anophagefferens (Pelagophyceae) through cDNA and qRT-PCR analysis. J Phycol 44:1235-1249

Berry S, Schneider D, Vermaas WF, Rogner M (2002) Electron transport routes in whole cells of Synechocystis sp. strain PCC6803: the role of the cytochrome bd-type oxidase. Biochemistry 41:3422-3429

Bhaya D, Dufresne A, Vaulot D, Grossman A (2002) Analysis of the hli gene family in marine and freshwater cyanobacteria. FEMS Microbiol Lett 215:209-219

Bibby TS, Mary I, Nield J, Partensky F, Barber J (2003) Lowlight adapted Prochlorococcus species possess specific antennae for each photosystem. Nature 424:1051-1054

Bouman HA, Ulloa O, Scanlan DJ, Zwirgimaier K and others (2006) Oceanographic basis of the global surface distribution of Prochlorococcus ecotypes. Science 312:918-921

Campbell D, Bruce D, Carpenter C, Gustafsson P, Öquist G (1996) Two forms of the photosystem II D1 protein alter energy dissipation and state transitions in the cyanobacterium Synechococcus sp. PCC7942. Photosynth Res 47:131-144

Campbell D, Eriksson MJ, Öquist G, Gustafsson P, Clarke AK (1998a) The cyanobacterium Synechococcus resists UV-B by exchanging photosystem II reaction centre D1 proteins. Proc Natl Acad Sci USA 95:364-369

Campbell D, Hurry V, Clarke AK, Gustafsson P, Öquist G (1998b) Chlorophyll fluorescence analysis of cyanobacterial photosynthesis and acclimation. Microbiol Mol Biol Rev 62:667-683

> Carol P, Kuntz M (2001) A plastid terminal oxidase comes to light: implications for carotenoid biosyntehsis and chlororespiration. Trends Plant Sci 6:31-36

Carol P, Stevenson D, Bisanz C, Breitenbach J and others (1999) Mutations in the Arabidopsis gene IMMUTANS cause a variegated phenotype by inactivating a chloroplast terminal oxidase associated with phytoene desaturation. Plant Cell 11:57-68

Clarke AK, Soitamo A, Gustafsson P, Öquist G (1993) Rapid interchange between two distinct forms of cyanobacterial photosystem II reaction-center protein D1 in response to photoinhibition. Proc Natl Acad Sci USA 90:9973-9977

Clarke AK, Campbell D, Gustafsson P, Öquist G (1995) Dynamic responses of the photosystem II and phycobilisomes to changing light in the cyanobacterium Synechococcus sp. PCC7942. Planta 197:553-562

Collier JL, Grossman AR (1992) Chlorosis induced by nutrient deprivation in Synechococcus sp. strain PCC 7942: not all bleaching is the same. J Bacteriol 174:4718-4726

Cournac L, Redding K, Ravenel J, Rumeau D and others (2000) Electron flow between PSII and oxygen in chloroplasts of PSI-deficient algae is mediated by a quinol oxidase involved in chlororespiration. J Biol Chem 275: 17256-17262

Fuller NJ, Tarran GA, Yallop M, Orcutt KM, Scanlan DJ (2006) Molecular analysis of picocyanobacterial community structure along an Arabian Sea transect reveals dis- tinct spatial separation of lineages. Limnol Oceanogr 51: 2515-2526

Funk C, Vermaas W (1999) A cyanobacterial gene family coding for single-helix proteins resembling part of the lightharvesting proteins from higher plants. Biochemistry 38 : 9397-9404

> Garczarek L, Dufresne A, Blot N, Cockshutt AM and others (2008) Function and evolution of the $p s b A$ gene family in marine Synechococcus: Synechococcus sp. WH7803 as a case study. ISME J 2:937-953

Glibert PM, Kana TM, Olson RJ, Kirchman DL, Alberte RS (1986) Clonal comparisons of growth and photosynthetic responses to nitrogen availability in marine Synechococcus spp. J Exp Mar Biol Ecol 101:199-208

> Grossman AR, Schaefer MR, Chiang GG, Collier JL (1993) The phycobilisome, a light-harvesting complex responsive to environmental conditions. Microbiol Rev 57:725-749

> Grossman AR, Bhaya D, He Q (2001) Tracking the light environment by cyanobacteria and the dynamic nature of light harvesting. J Biol Chem 276:11449-11452

Hart SE, Schlarb-Ridley BG, Bendall DS, Howe CJ (2005) Terminal oxidases of cyanobacteria. Biochem Soc Trans 33: 832-835

Havaux M, Guedeney G, He Q, Grossman AR (2003) Elimination of high-light-inducible polypeptides related to eukaryotic chlorophyll $a / b$-inducing proteins results in aberrant photoacclimation in Synechocystis PCC6803. Biochim Biophys Acta 1557:21-33

> He Q, Dolganov N, Bjorkman O, Grossman AR (2001) The high-light-inducible polypeptides in Synechocystis PCC6803-expression and function in high light. J Biol Chem 276:306-314

Holm-Hansen O, Lorenzen CJ, Holmes RW, Strickland JDH (1965) Fluormetric determination of chlorophyll. ICES J Mar Sci 30:3-15

> Josse EM, Simkin AJ, Gaffé J, Labouré AM and others (2000) A plastid terminal oxidase associated with carotenoid desaturation during chromoplast differentiation. Plant Physiol 123:1427-1436

> Kana T, Glibert PM (1987) Effect of irradiances up to $2000 \mu \mathrm{E}$ $\mathrm{m}^{-2} \mathrm{~s}^{-1}$ on marine Synechococcus WH7803-I. Growth, pigmentation, and cell composition. Deep-Sea Res 34: 479-495

Keren N, Berg A, van Kan PJ, Levanon H, Ohad II (1997) Mechanism of photosystem II photoinactivation and D1 protein degradation at low light: the role of back electron flow. Proc Natl Acad Sci USA 94:1579-1584

> Krupa Z, Öquist G, Gustafsson P (1991) Photoinhibition of photosynthesis and growth responses at different light levels in psbA gene mutants of the cyanobacterium Synechococcus. Physiol Plant 82:1-8

Kuntz M (2004) Plastid terminal oxidase and its biological significance. Planta 218:896-899

> Lindell D, Jaffe JD, Coleman ML, Futschik ME and others (2007) Genome-wide expression dynamics of a marine virus and host reveal features of co-evolution. Nature 449: $83-85$

Long SP, Humphries S, Falkowski PG (1994) Photoinhibition of photosynthesis in nature. Annu Rev Plant Physiol Plant Mol Biol 45:633-662

> McDonald AE, Vanlerberghe GC (2005) Alternative oxidase and plastoquinol terminal oxidase in marine prokaryotes of the Sargasso Sea. Gene 349:15-24

> McDonald AE, Amirsadeghi S, Vanlerberghe GC (2003) Prokaryotic orthologues of mitochondrial alternative oxidase and plastid terminal oxidase. Plant Mol Biol 53: 865-876 
Moore LR, Goericke R, Chisholm SW (1995) Comparative physiology of Synechococcus and Prochlorococcus: influence of light and temperature on growth, pigments, fluorescence and absorptive properties. Mar Ecol Prog Ser 116:259-275

Nishiyama Y, Allakhverdiev SI, Murata N (2006) A new paradigm for the action of reactive oxygen species in the photoinhibition of photosystem II. Biochim Biophys Acta 1757:742-749

Palenik B, Brahamsha B, Larimer FW, Land M and others (2003) The genome of a motile marine Synechococcus. Nature 424:1037-1042

Peltier G, Ravenel J, Vermeglio A (1987) Inhibition of a respiratory activity by short saturating flashes in Chlamydomonas-evidence for a chlororespiration. Biochim Biophys Acta 893:83-90

Platt TC, Gallegos L, Harrison WG (1980) Photoinhibition of photosynthesis in natural assemblages of marine phytoplankton. J Mar Res 38:687-701

Promnares K, Komenda J, Bumba L, Nebesarove J, Vacha F, Tichy M (2006) Cyanobacterial small chlorophyll-binding protein $\mathrm{ScpD}(\mathrm{HliB})$ is located on the periphery of photosystem II in the vicinity of PsbH and CP47 subunits. J Biol Chem 281:32705-32713

Ririe KM, Rasmussen RP, Wittwer CT (1997) Product differentiation by analysis of DNA melting curves during the polymerase chain reaction. Anal Biochem 270:154-160

Rocap G, Larimer FW, Lamerdin J, Malfatti S and others (2003) Genome divergence in two Prochlorococcus ecotypes reflects oceanic niche differentiation. Nature 424: 1042-1047

Rosso D, Ivanov AG, Fu A, Geisler-Lee J and others (2006) IMMUTANS does not act as a stress-induced safety valve in the protection of the photosynthetic apparatus of Arabidopsis during steady-state photosynthesis. Plant Physiol 142:574-585

Rozen S, Skaletsky HJ (2000) Primer3 on the WWW for general users and for biologist programmers. In: Krawetz S, Misener S (eds) Bioinformatics methods and protocols: methods in molecular biology. Humana Press, Totowa, NJ, p 365-386

Rumeau D, Peltier G, Cournac L (2007) Chlororespiration and cyclic electron flow around PSI during photosynthesis and plant stress response. Plant Cell Environ 30:1041-1051

Sambrook J, Fritsch EF, Maniatis T (1989) Molecular cloning: a laboratory manual, 2nd edn. Cold Spring Harbor Laboratory Press, New York, NY

Scanlan DJ, Ostrowski M, Mazard S, Dufresne A and others (2009) Ecological genomics of marine picocyanobacteria. Microbiol Mol Biol Rev 73:249-299

Schaefer MR, Golden SS (1989a) Light availability influences the ratio of 2 forms of D1 in cyanobacterial thylakoids. J Biol Chem 264:7412-7417

Schaefer MR, Golden SS (1989b) Differential expression of members of a cyanobacterial psbA gene family in response to light. J Bacteriol 171:3973-3981

Shahbazi M, Gilbert M, Laboure AM, Kuntz M (2007) Dual role of the plastid terminal oxidase in tomato. Plant Physiol 145:691-702

Simkin AJ, Laboure AM, Kuntz M, Sandmann G (2003) Comparison of carotenoid content, gene expression and enzyme levels in tomato (Lycopersicon esculentum) leaves. Naturforsch 58:371-380

- Six C, Thomas JC, Brahamsha B, Lemoine Y, Partensky F (2004) Photophysiology of the marine cyanobacterium Synechococcus sp. WH8102, a new model organism. Aquat Microb Ecol 35:17-29
Six C, Joubin L, Partensky F, Hltzendorff J, Garczarek L (2007a) UV-induced phycobilisome dismantling in the marine picocyanobacterium Synechoccus sp. WH8102. Photosynth Res 92:75-86

- Six C, Finkel ZV, Irwin AJ, Campbell DA (2007b) Light variability illuminates niche-partitioning among marine picocyanobacteria. PLoS ONE 2:e1341

Steglich C, Futschik M, Rector T, Steen R, Chisholm SW (2006) Genome-wide analysis of light sensing in Prochlorococcus. J Bacteriol 188:7796-7806

Su Z, Mao F, Dam P, Wu H and others (2006) Computational inference and experimental validation of the nitrogen assimilation regulatory network I cyanobacterium Synechococcus sp. WH 8102. Nucleic Acids Res 34:1050-1065

Ting CS, Rocap G, King J, Chishold SW (2002) Cyanobacterial photosynthesis in the oceans: the origins and significance of divergent light-harvesting strategies. Trends Microbiol 10:134-142

Tolonen AC, Aach J, Lindell D, Johson ZI and others (2006) Global gene expression of Prochlorococcus ecotypes in response to changes in nitrogen availability. Mol Syst Biol 2:53

- Vass I, Styring S, Hundal T, Koivuniemi A, Aro E, Andersson B (1992) Reversible and irreversible intermediates during photoinhibition of the photosystem II: stable reduced QA species promote chlorophyll triplet formation. Proc Natl Acad Sci USA 89:1408-1412

Wang Q, Jantaro S, Lu B, Majeed W, Bailey M, He Q (2008) The high light-inducible polypeptides stabilize trimeric photosystem I complex under high light conditions in Synechocystis PCC 6803. Plant Physiol 147:1239-1250

Waterbury JB, Watson SW, Valois FW, Franks DG (1986) Biological and ecological characterization of the marine unicellular cyanobacterium Synechococcus. In: Platt T, Li WKI (eds) Photosynthetic picoplankton. Can Bull Fish Aquatic Sci 214:71-120

Wetzel CM, Jiang CZ, Meehan LJ, Voytas DF, Rodermel SR (1994) Nuclear-organelle interactions: the immutans variegation mutant of Arabidopsis is plastid autonomous and impaired in carotenoid biosynthesis. Plant J 6:161-175

> Wyman M, Gregory RPF, Carr NG (1985) Novel role for phycoerythrin in a marine cyanobacterium, Synechococcus strain DC2. Science 230:818-820

Xu H, Vavilin D, Funk C, Vermaas W (2002) Small Cab-like proteins regulating tetrapyrrole biosynthesis in the cyanobacterium Synechocystis sp. PCC6803. Plant Mol Biol 49:149-160

Yamanaka G, Glazer AN (1980) Dynamic aspects of phycobilisome structure: phycobilisome turnover during nitrogen starvation in Synechococcus spp. Arch Microbiol 124: $39-47$

Yao D, Kieselbach T, Komenda J, Promnares K and others (2007) Localization of the small CAB-like proteins in photosystem II. J Biol Chem 282:267-276

Zinser ER, Lindell D, Johnson ZI, Futschik ME and others (2009) Choreography of the transcriptome, photophysiology, and cell cycle of a minimal photoautotroph, Prochlorococcus. PLoS ONE 4:e5135

Zwirglmaier K, Heywood JL, Chamberlain K, Woodward EMS, Zubkov MV, Scanlan DJ (2007) Basin-scale distribution patterns of picocyanobacterial lineages in the Atlantic Ocean. Environ Microbiol 9:1278-1290

Zwirglmaier K, Jardillier L, Ostrowski M, Mazard S and others (2008) Global phylogeography of marine Synechococcus and Prochlorococcus reveals a distinct partitioning of lineages among oceanic biomes. Environ Microbiol 10: $147-161$ 